\title{
Аналіз клініко-функціональних характеристик хронічного обструктивного захворювання легень та коморбідної патології в учасників ліквідації наслідків аварії на Чорнобильській АEC у віддалений післяаварійний період
}

\section{К.Д. Базика}

Державна установа «Національний науковий центр радіаційної медицини Національної академії медичних наук України», Київ, Україна

\begin{abstract}
Анотація. Мета дослідження: проаналізувати клініко-функціональні характеристики перебігу хронічного обструктивного захворювання легень (ХОЗЛ) та супутні захворювання в учасників ліквідації наслідків аварії на Чорнобильській АЕС (ЧАЕС) у динаміці. Об'єкт і методи дослідження. Згідно з критеріями включення відібрано 172 хворих на ХОЗЛ різного ступеня тяжкості: основна група - 142 учасники ліквіда-

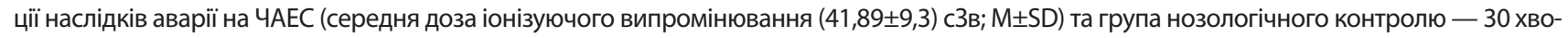
рих, які не зазнали впливу іонізуючого випромінювання. На базі відділення пульмонології відділу терапії радіаційних наслідків Інституту клінічної радіології Національного наукового центру радіаційної медицини проведено проспективне загальноклінічне та функціональне обстеження хворих. Тривале спостереження впродовж 8 років проведено у 40 хворих на ХОЗЛ. Результати. Встановлено, що за відсутності різниці у показниках, які характеризують стадію ХОЗЛ, у ліквідаторів наслідків аварії на ЧАЕС задишка була вираженішою за шкалою Medical Research Council. В основній групі відмічали вищу частоту супутніх захворювань, зокрема ішемічної хвороби серця, артеріальної гіпертензії, незлоякісних захворювань щитоподібної залози, захворювань шлунково-кишкового тракту та нервової системи. Впродовж динамічного спостереження відмічено тенденцію до підвищення частоти виявлення клінічних ознак порушення стану бронхолегеневої системи в усіх хворих на ХОЗЛ, але більш виражена негативна динаміка у групі учасників ліквідації наслідків аварії на ЧАЕС.
\end{abstract}

Ключові слова: хронічне обструктивне захворювання легень, діагностика ХОЗЛ, коморбідна патологія, аварія на Чорнобильській АЕС.

\section{Вступ}

Хронічне обструктивне захворювання легень (ХОЗЛ) одна з найбільш серйозних всесвітніх медико-соціальних проблем [1-4]. Це зумовлено передусім надзвичайно високою поширеністю, інвалідизацією та смертністю. Смертність, пов'язана 3 ХОЗЛ, нестримно зростає з кожним роком. Також дуже важливим чинником, що зумовлює актуальність проблеми ХОЗЛ, $\epsilon$ висока вартість цієї патології для систем охорони здоров'я і суспільства в цілому $[2,3]$. Згідно з даними Глобальної ініціативи по боротьбі з ХОЗЛ (Global Initiative for Chronic Obstructive Lung Disease - GOLD) [4] у Європейському Союзі щорічні прямі витрати на ХОЗЛ досягають 38,6 млрд євро. У США в 2015 р. цей показник становив 21,8 млрд дол. США, а непрямі витрати перевищили 17 млрд дол.

Одним із впливових факторів, що визначають прогноз при ХОЗЛ, $\epsilon$ наявність системних проявів захворювання та коморбідних станів. Загалом у популяції наявність паралельно існуючих захворювань суттєво підвищується з віком - $310 \%$ у осіб віком $<19$ років до $80 \%$ у осіб віком $\geq 80$ років. Оскільки хворі на ХОЗЛ - здебільшого пацієнти літнього віку, наявність значущої коморбідної патології в них потребує підвищеної уваги з боку науковців та практикуючих лікарів. Але при цьому захворюванні значна поширеність коморбідних станів не може бути пояснена тільки похилим віком пацієнтів $[5,6]$.

Причин стрімкого зростання частоти ХОЗЛ досить багато: погіршення умов довкілля, прогресуюче старіння населення, тютюнопаління $[2-4,7]$. Поширення нікотинової залежності в Україні вражає: >58\% чоловіків та 14\% жінок вважають себе курцями; серед підлітків віком 13-16 років цей відсоток становить 46,8\%, що в сукупності вивело нашу державу на 1-ше місце серед країн Європи [2]. Крім того, на території України відбулася найбільша техногенна катастрофа - аварія на Чорнобильській АЕС (ЧАЕС), внаслідок чого, за різними оцінками, інгаляційної дії радіонуклі- дів зазнали щонайменше 200 тис. постраждалих різних категорій. 3 них найбільш ураженою та однією 3 найчисленніших категорій $є$ учасники ліквідації наслідків аварії (УЛНА), особливо ті з них, хто був причетний до післяаварійних робіт у квітні-травні 1986 р., а також протягом усього періоду до завершення будівництва об'єкту «Укриття»— весни 1987 р.

За таких умов інгаляція радіонуклідів була одним з основних шляхів їх надходження в організм УЛНА на ЧАЕС, які працювали в 30-кілометровій зоні навколо станції. Різноманітний спектр радіоактивних ізотопів, зокрема тих, що входять до складу «гарячих» часток, обумовлює труднощі прогнозування віддалених радіаційних наслідків [3-5, 7-10].

Мета роботи: проаналізувати клініко-функціональні характеристики перебігу ХОЗЛ та супутні захворювання в УЛНА на ЧАЕС у динаміці.

\section{Об'єкт і методи дослідження}

До групи спостереження увійшли 172 хворих на ХОЗЛ IIIII стадії за GOLD [4]: основна група - 142 УЛНА на ЧАЕС та група нозологічного контролю (НК) - 30 хворих, які не зазнали впливу іонізуючого випромінювання.

На базі відділення пульмонології відділу терапії радіаційних наслідків Інституту клінічної радіології Національного наукового центру радіаційної медицини (ІКР ННЦРМ) відповідно до розробленого протоколу усім обстеженим проводили аналіз супутніх захворювань шляхом вивчення медичної документації, загальноклінічне фізикальне обстеження, аналіз рівня задишки за шкалою Medical Research Council (MRC), спірографію, загальний аналіз крові та біохімічне дослідження крові.

За віком обстежені досліджуваних груп достовірно не відрізнялися: середній вік хворих основної групи становив 63,8 $\pm 1,6$ року, групи HK $-61,7 \pm 1,8$ року $(\mathrm{M} \pm \mathrm{SD})$. Усі хворі були чоловічої статі. Індивідуальні документовані дози радіаційного випромі- 
нювання УЛНА на ЧАЕС, обстежених в стаціонарних умовах, ста-

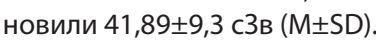

Курінням зловживали 76,7\% пацієнтів (в основній групі $80 \%$, в групі НК - 70\%). Показник пачко-років в основній групі

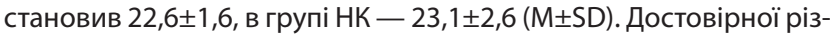
ниці між групами за цим показником не виявлено. Обстеження проводили у стабільному стані ХОЗЛ, поза загостренням.

Розподіл хворих за ступенем тяжкості ХОЗЛ був рівномірним у групах спостереження. У $58(40,8 \%)$ УЛНА на ЧАЕС та $13(43,3 \%)$ осіб НК) відмічено II та 46 (32,4\%) та 10 (33,3\%) відповідно — III ступінь тяжкості ХОЗЛ. Пацієнтів I (27 (19,0\%) та 5 (16,7\%) відповідно) та вкрай тяжкого (IV) ступеня тяжкості ХОЗЛ (11 (7,8\%) та 2 (6,7\%) відповідно) було менше, ніж спостерігається і в популяції цих хворих.

Таким чином, учасники досліджуваних груп не відрізнялися між собою за основними показниками, які характеризують ХОЗЛ, за винятком наявності або відсутності впливу іонізуючого випромінювання.

\section{Результати та їх обговорення}

Розподіл хворих був рівномірним у групах спостереження як за ступенем тяжкості ХОЗЛ, так і за тривалістю хвороби (середній стаж захворювання від дати встановлення діагнозу $12,3 \pm 3,2$ року у групі УЛНА на ЧАЕС та 13,5 $\pm 4,3$ року у групі НК; $p>0,05)$, що дозволило провести порівняльний аналіз клінічного перебігу та стану респіраторної системи у обстежених осіб.

Аналіз патогномонічних для захворювань бронхолегеневої системи (БЛС) симптомів засвідчив наявність кашлю, виділення мокротиння, задишки у більшості хворих на ХОЗЛ як в основній групі, так і в групі НК (табл. 1).

Аналіз показав, що у хворих основної групи частіше відмічали скарги на сухий кашель, а також на задишку різного ступеня інтенсивності. Кашель зі слизово-гнійним мокротинням, навпаки, частіше виявляли в групі НК.

Аналіз клінічних ознак ХОЗЛ свідчить, що в УЛНА на ЧАЕС задишка переважала над рештою респіраторних симптомів.

Індекс маси тіла достовірно не відрізнявся у групах спостереження, однак слід відзначити, що у хворих на ХОЗЛ, які курили,

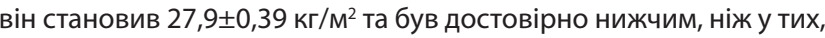

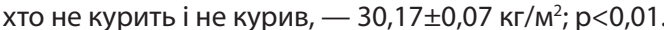

За результатами обстеження хворих на ХОЗЛ встановлено, що за відсутності різниці в показниках, які характеризують стадію ХОЗЛ (об'єм форсованого видиху за 1-шу секунду), в УЛНА на ЧАЕС порівняно з групою НК виявлено достовірно гірші показники ступеня задишки (MRC) $(2,3 \pm 0,4$ бала у групі УЛНА на ЧАЕС та $1,6 \pm 0,2$ у групі HК; $p<0,01)$ та збільшення кількості загострень на рік $(2,8 \pm 0,8$ та $1,7 \pm 0,4$ відповідно; $p<0,01)$.

Ступінь тяжкості задишки за шкалою MRC у групах спостереження хворих на ХОЗЛ корелював зі ступенем тяжкості ХОЗЛ. Найбільшу кількість становили хворі із задишкою I ступеня як серед УЛНА на ЧАЕС, так і у групі НК. Достовірних відмінностей за ступенем задишки у групах спостереження не виявлено, за винятком більшої кількості хворих з задишкою I ступеня в основній групі.

За результатами вивчення анамнезу хвороби безперервнорецидивуючий характер перебігу хронічного бронхіту відмічали в усіх УЛНА на ЧАЕС. На відміну від них, хворі на ХОЗЛ без радіаційного фактору в анамнезі підкреслювали чітку зміну періодів загострень та ремісії хвороби.

Загальновідомо, що в основі ХОЗЛлежить тривалий запальний процес, який стосується всіх структур легеневої тканини (бронхів, бронхіол, альвеол, легеневих судин), проте часто «класичне» локальне запалення набуває системного характеру, при якому докорінно змінюється суть запального процесу. Хронічне системне запалення - типовий мультисиндромний патологічний процес, що розвивається при системному пошкодженні і характеризується тотальною запальною реактивністю ендотеліоцитів, плазмових і клітинних факторів крові та сполучної тканини, а на заключних етапах - і мікроциркуляторними розладами у життєво важливих органах і тканинах. Реакція мікросудин (особливо посткапілярних венул) має тотальний характер і впливає на абсолютно всі органи, у зв'язку з чим можна зробити висновок, що мікроциркуляторні розлади $\epsilon$ ключовими складовими хронічного запального процесу. Крім того, хронічний запальний процес проявляється оксидативним стресом, підвищенням концентрації циркулюючих цитокінів та активацією численних клітин запалення, що синтезують власні медіатори.

Метаболічні порушення, які відмічають при ХОЗЛ, призводять до розвитку інших захворювань. У процесі вивчення клінічного перебігу ХОЗЛ в УЛНА на ЧАЕС проаналізовані супутні захворювання в основній та контрольній групах (табл. 2).

Аналіз супутніх захворювань в УЛНА на ЧАЕС порівняно 3 хворими на ХОЗЛ з групи НК виявив достовірно вищу частоту ішемічної хвороби серця (61,8 та $36,7 \%$ відповідно; $p<0,05)$, артеріальної гіпертензії $(80,2$ та 60,0\% відповідно; $\mathrm{p}<0,05)$, незлоякісних захворювань щитоподібної залози (28,0 та 10,0\% відповідно; $\mathrm{p}<0,05)$, захворювань шлунково-кишкового тракту $(58,4$ та $20,0 \%$ відповідно; $p<0,05)$ та захворювань нервової системи $(80,9$ та 40,0\% відповідно; $p<0,05)$.

Усім обстеженим відповідно до розробленого протоколу проводили загальний аналіз крові та біохімічне дослідження крові.

Так, показник відносної кількості еозинофілів був достовірно вищим в УЛНА на ЧАЕС, які хворіють на ХОЗЛ, порівняно з хворими на ХОЗЛ, які зазнали дії іонізуючого випромінювання у межах радіаційного фону. Виявлені зміни можуть опосередковано свідчити про дещо інший фенотип ХОЗЛ в УЛНА на ЧАЕС, який характеризується підвищеним рівнем еозинофілів та може потребувати призначення у якості базисної терапії, окрім бронхолітичних препаратів, інгаляційних глюкокортикостероїдів (табл. 3).

За результатами вивчення показників біохімічного дослідження крові виявлено підвищений рівень холестерину у групі Хворих на ХОЗЛ УЛНА на ЧАЕС порівняно з групою НК (табл. 4). Крім того, в УЛНА на ЧАЕС, які хворіють на ХОЗЛ, відмічали достовірно вищий рівень креатиніну порівняно з групою НК, який не виходив за рамки нормальних значень.

Також виявлено, що кількість осіб, рівень холестерину сироватки крові яких був вищий ніж 6 ммоль/л, була достовірно біль-

Таблиця 1 Частота клінічних ознак порушення стану БЛС у хворих на ХОЗЛ, які зазнали інгаляційного впливу іонізуючого випромінювання, та осіб групи НК, абсолютний показник (\%)

\begin{tabular}{lccc}
\hline \multirow{2}{*}{\multicolumn{1}{c}{ Клінічні ознаки }} & \multicolumn{2}{c}{ Групи хворих на Х0зЛ } & \\
\cline { 2 - 3 } & $\begin{array}{c}\text { улНА на чАЕС } \\
\text { (n=142) }\end{array}$ & $\begin{array}{c}\text { HK } \\
\text { (n=30) }\end{array}$ & p \\
\hline Сухий кашель & $84(59,1)^{*}$ & $17(53,3)$ & $>0,05$ \\
\hline Кашель зі слизовим мокротинням & $42(29,6)$ & $26(34,7)$ & $>0,05$ \\
\hline Кашель зі слизово-гнійним мокротинням & $7(4,9)^{*}$ & $6(20,0)$ & $<0,05$ \\
\hline Задишка при швидкій ході & $82(57,7)^{*}$ & $11(33,3)$ & $<0,05$ \\
\hline Коробковий відтінок перкуторного звуку & $91(64,1)$ & $18(60,0)$ & $>0,05$ \\
\hline Поодинокі сухі хрипи в легенях & $88(61,9)^{*}$ & $13(43,3)$ & $<0,001$ \\
\hline Розсіяні сухі хрипи в легенях & $24(16,9)$ & $5(16,6)$ & $>0,05$ \\
\hline
\end{tabular}

*Достовірні відмінності у групах спостереження; $p<0,05$.

Таблиця 2 Розподіл хворих на ХОЗЛ за супутніми захворюваннями

\begin{tabular}{lccc}
\hline \multirow{2}{*}{ Ступінь тяжкості задишки } & \multicolumn{2}{c}{ Групи хворих на Х0зл } & \\
\cline { 2 - 3 } & $\begin{array}{c}\text { УлНА на ЧАЕС } \\
\text { (n=142) }\end{array}$ & $\begin{array}{c}\text { HK } \\
\text { (n=30) }\end{array}$ & \\
\hline Ішемічна хвороба серця & $88(61,8)^{*}$ & $11(36,7)$ & $<0,05$ \\
\hline Артеріальна гіпертензія & $114(80,2)^{*}$ & $18(60,0)$ & $<0,05$ \\
\hline Аритмія & $32(22,5)$ & $7(23,3)$ & $>0,05$ \\
\hline Захворювання щитоподібної залози & $54(28,0)$ & $3(10,0)$ & $<0,05$ \\
\hline Цукровий діабет & $17(11,8)$ & $2(6,7)$ & $>0,05$ \\
\hline Захворювання шлунково-кишкового & $83(58,4)^{*}$ & $6(20,0)$ & $<0,05$ \\
\hline тракту & $115(80,9)^{*}$ & $12(40,0)$ & $<0,05$ \\
\hline Захворювання нервової системи & & &
\end{tabular}

*Достовірні відмінності у групах спостереження; $\mathrm{p}<0,05$. 
шою у групі пацієнтів, які хворіють на ХОЗЛ (42,9\% у групі хворих на ХОЗЛ порівняно з 26,7\% у групі НК).

Окремо із загального числа учасників додатково відібрано 40 хворих на ХОЗЛ (30 УЛНА на ЧАЕС та 10 хворих групи НК), яких спостерігали у відділенні пульмонології відділу терапії радіаційних наслідків ІКР ННЦРМ впродовж 8 років, та проведено ретроспективний та поточний аналіз перебігу ХОЗЛ (табл. 5).

Впродовж динамічного спостереження встановлено тенденцію до підвищення частоти виявлення клінічних ознак по-

Таблиця 3 Результати загального аналізу крові в УЛНА на ЧАЕС та осіб групи $\mathrm{HK}, \mathrm{M} \pm \mathrm{SD}$

\begin{tabular}{|c|c|c|c|}
\hline \multirow[b]{2}{*}{ Показник } & \multicolumn{2}{|c|}{ Групи хворих на Х0зЛ } & \multirow[b]{2}{*}{$\mathbf{p}$} \\
\hline & $\begin{array}{c}\text { УЛНА на ЧАЕС } \\
(n=142)\end{array}$ & $\begin{array}{c}\text { HK } \\
(n=30)\end{array}$ & \\
\hline Еритроцити, $\cdot 10^{12} / л$ & $5,10 \pm 0,49$ & $5,01 \pm 0,41$ & $>0,05$ \\
\hline Гемоглобін, г/л & $151,46 \pm 11,39$ & $152,63 \pm 7,71$ & $>0,05$ \\
\hline Тромбоцити, · $10 \%$ л & $230,76 \pm 65,48$ & $245,75 \pm 72,02$ & $>0,05$ \\
\hline Лейкоцити, $\cdot 10^{12} / л$ & $6,81 \pm 1,44$ & $6,95 \pm 1,07$ & $>0,05$ \\
\hline Базофіли, \% & $1,0 \pm 0,6$ & - & $>0,05$ \\
\hline Еозинофіли, \% & $3,08 \pm 1,68^{*}$ & $2,0 \pm 1,41$ & $<0,05$ \\
\hline Паличкоядерні, \% & $2,46 \pm 1,27$ & $3,5 \pm 1,91$ & $>0,05$ \\
\hline Сегментоядерні, \% & $56,22 \pm 8,48$ & $61,43 \pm 7,59$ & $>0,05$ \\
\hline Лімфоцити, \% & $31,45 \pm 8,15$ & $28,3 \pm 6,47$ & $>0,05$ \\
\hline Моноцити, \% & $9,69 \pm 3,22$ & $8,51 \pm 3,25$ & $>0,05$ \\
\hline Швидкість осідання еритроцитів & $8,79 \pm 8,88$ & $6,0 \pm 2,71$ & $>0,05$ \\
\hline
\end{tabular}

*Достовірні відмінності у групах спостереження, $p<0,05$.

Таблиця 4 Результати біохімічного аналізу крові в УЛНА на ЧАЕС та осіб групи $\mathrm{HK}, \mathrm{M} \pm \mathrm{SD}$

\begin{tabular}{|c|c|c|c|}
\hline \multirow[b]{2}{*}{ Показник } & \multicolumn{2}{|c|}{ Групи хворих на Х0зЛ } & \multirow[b]{2}{*}{ p } \\
\hline & $\begin{array}{c}\text { УЛНА на ЧАЕС } \\
(n=142)\end{array}$ & $\begin{array}{c}\text { HK } \\
(n=30)\end{array}$ & \\
\hline Білок загальний, г/л & $75,55 \pm 4,95$ & $75,71 \pm 4,9$ & $>0,05$ \\
\hline Білірубін загальний, мкмоль/л & $14,66 \pm 6,09$ & $16,9 \pm 7,15$ & $>0,05$ \\
\hline Білірубін прямий, мкмоль/л & $4,0 \pm 1,5$ & $4,29 \pm 1,49$ & $>0,05$ \\
\hline Глюкоза, ммоль/л & $5,71 \pm 1,29$ & $5,6 \pm 0,75$ & $>0,05$ \\
\hline Сечовина, мкмоль/л & $6,23 \pm 1,85$ & $5,8 \pm 1,35$ & $>0,05$ \\
\hline Креатинін, мкмоль/л & $109,27 \pm 18,61^{*}$ & $102,6 \pm 12,18$ & $<0,05$ \\
\hline Аланінамінотрансфераза, од./л & $26,11 \pm 12,19$ & $21,75 \pm 14,28$ & $>0,05$ \\
\hline Аспартатамінотрансфераза, од./л & $26,46 \pm 8,97$ & $27,25 \pm 8,73$ & $>0,05$ \\
\hline В-ліпопротеїни, ммоль/л & $42,41 \pm 11,37$ & $43,75 \pm 11,24$ & $>0,05$ \\
\hline Холестерин, ммоль/л & $5,52 \pm 1,34^{*}$ & $4,46 \pm 1,74$ & $<0,05$ \\
\hline
\end{tabular}

*Достовірні відмінності у групах спостереження; $\mathrm{p}<0,05$.

Таблиця 5 Результати аналізу окремих клінічних ознак порушення стану БЛС у хворих на ХОЗЛ, які зазнали інгаляційного впливу іонізуючого випромінювання, та осіб групи НК, абсолютний показник (\%)

\begin{tabular}{ccc}
\hline & \multicolumn{2}{c}{ Групи хворих на Х0ЗЛ } \\
\cline { 2 - 3 } Клінічні ознаки & $\begin{array}{c}\text { УЛНА на ЧАЕС } \\
(\mathrm{n}=30)\end{array}$ & $\begin{array}{c}\text { НК } \\
(\mathrm{n}=10)\end{array}$
\end{tabular}

2008 p. 2012 p. 2016 p. 2008 p. 2012 p. 2016 p.

\begin{tabular}{lcccccc}
\hline Сухий кашель & $16(53,3)$ & $17(56,6)$ & $19(63,3)$ & $4(40,0)$ & $4(40,0)$ & $5(50,0)$ \\
\hline $\begin{array}{l}\text { Кашель зі слизовим } \\
\text { мокротинням }\end{array}$ & $11(36,7)$ & $9(30,0)$ & $8(26,7)$ & $4(40,0)$ & $3(30,0)$ & $2(20,0)$ \\
\hline $\begin{array}{l}\text { Кашель зі слизово-гнійним } \\
\text { мокротинням }\end{array}$ & $3(10,0)$ & $4(13,3)$ & $3(10,0)$ & $2(20,0)$ & $3(30,0)$ & $3(30,0)$ \\
\hline Задишка при швидкій ході & $14(46,7)$ & $17(56,6)$ & $20(66,7)$ & $2(20,0)$ & $3(30,0)$ & $3(30,0)$ \\
\hline $\begin{array}{l}\text { Коробковий відтінок } \\
\text { перкуторного звуку }\end{array}$ & $12(40,0)$ & $16(53,3)$ & $19(63,3)$ & $4(40,0)$ & $5(50,0)$ & $5(50,0)$ \\
\hline Поодинокі сухі хрипи в легенях & $15(50,0)$ & $18(60,0)$ & $21(70,0)$ & $3(30,0)$ & $3(30,0)$ & $4(40,0)$ \\
\hline Розсіяні сухі хрипи в легенях & $4(13,3)$ & $7(23,3)$ & $9(30,0)$ & $2(20,0)$ & $2(20,0)$ & $3(30,0)$ \\
\hline
\end{tabular}

рушення стану БЛС у хворих на ХОЗЛ в обох групах, але більш виражена негативна динаміка зафіксована у групі УЛНА на ЧАЕС, особливо задишка при швидкій ході (46,6\% пацієнтів відмічали наявність в 2008 р., 56,6\% — в 2012 р. та 66,7\% - в 2016 р.), коробковий відтінок перкуторного звуку (40,0\% в 2008 р., 53,3\% в 2012 р. та 63,3\% - в 2016 р.), поодинокі сухі хрипи в легенях (50,0\% в 2008 р., 60,0\% - в 2012 р. та 70,0\% - в 2016 р.), розсіяні сухі хрипи в легенях (13,3\% в 2008 р., 23,3\% - в 2012 р. та 30,0\% - в 2016 р.).

Отримані результати свідчать про швидше прогресування ХОзЛ в осіб основної групи та ще раз підтверджують необхідність приділяти підвищену увагу цій когорті хворих з боку держави та медичних працівників. Для верифікації респіраторних порушень на більш ранніх стадіях прогресування ХОЗЛ в УЛНА на ЧАЕС слід обов'язково включати в план обстеження пульмонологічні опитувальники та бальну оцінку стану БЛС, загальноклінічні лабораторні дослідження, що дозволить призначати адекватну терапію, розробляти індивідуальний план диспансерного спостереження та програму реабілітаційних заходів.

\section{ВИСНОВКИ}

Узагальнюючи результати оцінки клінічного стану БЛС в УЛНА на ЧАЕС, зазначимо, що за відсутності різниці у показниках, які характеризують стадію ХОЗЛ, в УЛНА на ЧАЕС порівняно 3 групою НК достовірно частіше виявляли скарги на сухий кашель та задишку різного ступеня інтенсивності. Кашель зі слизовогнійним мокротинням, навпаки, частіше відмічали в групі НК.

При проведенні оцінки показників ступеня задишки (MRC)

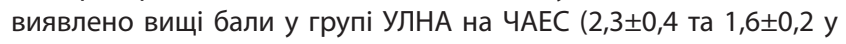
групах відповідно; $\mathrm{p}<0,01)$ та більшу кількість загострень на рік $(2,8 \pm 0,8$ та $1,7 \pm 0,4$ відповідно; $p<0,01)$.

При аналізі результатів загальноклінічних лабораторних досліджень виявлено достовірно вищий рівень відносної кількості еозинофілів у групі УЛНА на ЧАЕС, які хворіють на ХОЗЛ, та достовірно вищий рівень холестерину та креатиніну в основній групі порівняно з групою НК.

Аналіз супутніх захворювань виявив достовірно вищу частоту коморбідної патології, зокрема ішемічної хвороби серця, артеріальної гіпертензії, незлоякісних захворювань щитоподібної залози, захворювань шлунково-кишкового тракту та захворювань нервової системи в УЛНА на ЧАЕС, які хворіють на ХОЗЛ.

Відмічено тенденцію до підвищення частоти виявлення клінічних ознак порушення стану БЛС в усіх хворих на ХОЗЛ впродовж динамічного спостереження, але більш виражена негативна тенденція виявлена у групі УЛНА на ЧАЕС.

За результатами аналізу стану БЛС у хворих на ХОЗЛ УЛНА на ЧАЕС підтверджена необхідність обов'язкового динамічного спостереження для визначення адекватної терапії з урахуванням супутніх захворювань.

\section{Список використаної літератури/References:}

1. Feshchenko Yu.I. (2019) Adapted clinical guidelines: chronic obstructive pulmonary disease (part 1). New edition of the global COPD initiative. Ukr. Pulmonol. J., 2: 5-18. (In Ukr.).

2. GBD 2013 (2015) Mortality and Causes of Death Collaborators. Global, regional, and national age-sex specific all-cause and cause-specific mortality for 240 causes of death, 1990-2013: a systematic analysis for the Global Burden of Disease study 2013. Lancet, 385: 117-171 (www.who.int/respiratory/copd/burden/en/index.html).

3. Shvaiko L.I. (2015) Risk factors and prevention of chronic bronchopulmonary diseases. Proceedings of the scientific conference with international participation «Implementation of the National Action Plan on Noncommunicable Diseases in accordance with the European Strategy» Health 2020: Fundamentals of European policy in support of state and society in the interests of health and well-being», 30-31 Mar., 14 p. (In Ukr.).

4. http://www.goldcopd.org/uploads/users/files/GOLD_Report.pdf

5. Makhlouf H.A., Sadek S.H., Nafady A. (2018) Comorbidome, pattern, and impact of asthmaCOPD overlap syndrome in real life. Clin. Respir. J., 12: 48-56.

6. van den Akker M., Buntinx F., Metsemakers J.F. et al. (1998) Multimorbidity in general practice: prevalence, incidence, and determinants of c0-occurring chronic and recurrent diseases. J. Clin. Epidemiol., 51(5):367-375. doi: 10.1016/s0895-4356(97)00306-5. 
7. Shvaiko L.I., Bazyka K.D., Sushko V.O., Masyuk S.V. (2018) Chronic obstructive pulmonary disease in participants in the liquidation of the consequences of the Chernobyl accident in the remote post-accident period (clinical study). Probl. Rad. Med. Radiobiol., Kyiv, 490-499 p. (In Ukr.).

8. Sushko V.0., Nechaev S.Yu., Shvaiko L.I. et al. (2011) Bronchopulmonary system. Medical consequences of the Chernobyl disaster: 1986-2011. TSMU, Ternopil, 460-506 p. (In Ukr.).

9. Sushko V.0., Shvaiko L.I., Bazyka K.D. et al. (2016) The results of a thirty-year study of the state of the bronchopulmonary system in participants in the aftermath of the Chernobyl disaster. NAMS of Ukraine J., 2: 193-197. (In Ukr.).

10. Sushko V.O., Shvaiko L.I., Bazyka K.D. et al. (2016)Defeat of the bronchopulmonary system in the participants of the liquidation of the consequences of the Chernobyl accident (1988-2016). Thirty years of the Chernobyl disaster: radiological and medical consequences. National report of Ukraine. Kyiv, 126-130 p. (In Ukr.).

\section{Analysis of clinical and functional characteristics of COPD and comorbid pathology in clean-up workers of Chornobyl NPP accident in a remote post-accident period}

\section{K.D. Bazyka}

State Institution «National Research Center for Radiation Medicine of the National Academy of Medical Sciences of Ukraine», Kyiv, Ukraine

\section{Відомості про автора:}

Базика Костянтин Дмитрович - кандидат медичних наук, провідний науковий співробітник відділення пульмонології відділу терапії радіаційних наслідків державної установи «Національний науковий центр радіаційної медицини НАМН України», Київ, Україна.

\section{Адреса для кореспонденції:}

Базика Костянтин Дмитрович

04050, Київ, вул. Мельникова, 53

E-mail:kosncrm@ukr.net
Abstract. The aim of the study: to analyze the clinical and functional characteristics of the course of chronic obstructive pulmonary disease (COPD) and concomitant diseases in clean-up workers of Chornobyl NPP (ChNPP) accident in dynamics. Research object and methods. According to the inclusion criteria were selected for 172 patients with COPD varying severity: major group - 142 clean-up workers of ChNPP accident (mean dose of ionizing radiation 41.89 $\pm 9.3 \mathrm{cSv}, \mathrm{M} \pm \mathrm{SD}$ ) and a group a nosological control - 30 patients not exposed to ionizing radiation. On the basis of the pulmonology department of the department of treatment of radiation consequences of Institute for Clinical Radiology of the National Research Center for Radiation Medicine, a prospective general clinical and functional examination of patients was carried out. Long-term observation for 8 years was carried out in 40 patients with COPD. Results. It was found that in the absence of a difference in the indicators characterizing the stage of COPD, the clean-up workers of ChNPP accident had more pronounced dyspnea on the Medical Research Council scale. In the main group, concomitant diseases were more often observed, in particular ischemic heart disease, arterial hypertension, non-malignant diseases of the thyroid gland, diseases of the gastrointestinal tract and the nervous system. During the dynamic observation, a tendency to an increase in the frequency of detection of clinical signs of impairment of the state of the bronchopulmonary system in all patients with COPD was noticed, but a more pronounced negative dynamics was in the group of participants of the clean-up workers of ChNPP accident.

Key words: chronic obstructive pulmonary disease, diagnosis of COPD, comorbid pathology, Chornobyl NPP accident.

\section{Information about the author:}

Bazyka Kostyantin D. - Candidate of Medical Sciences, Leading researcher of the Pulmonology Department of Radiation effects therapy Department, State Institution «National Research Center for Radiation Medicine of the National Academy of Medical Sciences of Ukraine», Kyiv, Ukraine.

\section{Address for correspondence:}

Kostyantin Bazyka

04050, Kyiv, Melnykova str., 53

E-mail: kosncrm@ukr.net 